\title{
Determination of Leadership Behavior, Spiritual Intelligence Motivation in Riau Islands Work Satisfaction as Intervening Variables in the Sea and Fisheries of the Riau Islands Province
}

\author{
Eka Okta Hapriyana Chablullah Wibisono Bambang Satriawan Sri Yanti \\ Master Program in Management, Batam University, Riau Islands, Indonesia
}

\begin{abstract}
This study aims to determine and analyze five main variables, namely leadership behavior (X1), work motivation (X2) and spiritual intelligence (X3) which are independent variables, employee performance (Y) as an intervening variable and job satisfaction $(\mathrm{Z})$ as the dependent variable by obtaining data from respondents' answers to questionnaires that have been distributed. This study uses judgmental techniques (purposive) to get a sample of 120 employees of the Department of Maritime Affairs and Fisheries of the Riau Islands Province. To determine the direct and indirect effects between variables, as well as a set of variables on other variables, seen through the calculation of path coefficients and significance by testing hypotheses using statistical tests assisted by SPSS version 22 and AMOS (Analysis Moment of Structural) version 24. The results showed the leadership behavior variable (X1) directly determined the employee performance variable (Y) positively and significantly with the CR value $=4.124$ on probability $=(* * *)(\mathrm{p}<0.05)$, the work motivation variable $(\mathrm{X} 2)$ determined directly on employee performance variables $(Y)$ significantly positive with a $C R$ value $=3.101$ on probability $=0.002(p>0.05)$, the variable spiritual intelligence (X3) determines directly on employee performance variables (Y) positively and significantly with $C R$ values $=2.078$ at probability $=0.038(\mathrm{p}<0.05)$, leadership behavior variable $(\mathrm{X} 1)$ determines the job satisfaction variable $(Z)$ is positive and significant with $C R=2.836$ at probability $=0.005(p<0.05)$, motivation variable work $(\mathrm{X} 2)$ determines the job satisfaction variable $(\mathrm{Z})$ is positive and significant with a $C R$ value of 2.842 at probability $=0.004(\mathrm{p}>0.05)$, the variable of spiritual intelligence $(\mathrm{X} 3)$ determines the job satisfaction variable $(Z)$ is positive not significant with the value of $C R=1,303$ at probability $=0,193(p>0.05)$, and employee performance variables determine the job satisfaction variable $(Z)$ with the value of $C R=3,349$ on probability $=(* * *)(p<0.05)$ so can be stated positively and significantly. The conclusion of this study is the variable of leadership behavior, work motivation and spiritual intelligence largely determine the performance of employees and job satisfaction of the Office of Maritime Affairs and Fisheries of the Riau Islands Province. In addition, the performance of employees also largely determines the job satisfaction of employees of the Marine and Fisheries Office of Riau Islands Province.
\end{abstract}

Keywords: Leadership Behavior, Work Motivation, Spiritual Intelligence, Employee performance, and Job Satisfaction.

DOI: $10.7176 / \mathrm{EJBM} / 12-21-02$

Publication date:July $31^{\text {st }} 2020$

\section{Introduction}

UU no. 32 of 2004 is one of the principles that form the basis of the implementation of regional autonomy which includes the principles of decentralization, the principle of deconcentration and the principle of co-administration, according to Law No. 32 of 2004 explicitly states that decentralization is the transfer of governmental authority by the central government to autonomous regions to regulate and manage their government affairs in the unitary system of the Republic of Indonesia. Performance is a description of the level of achievement of the implementation of the tasks of a program of activities or policies in realizing the goals, objectives, vision, and mission of the agency as outlined in strategic planning, performance can be measured or assessed if the individual or employee already has criteria or standards of success that have been set by the agency. Human resources are a very important element to achieve success where their existence must be considered, managed and improved in quality. The problem of leadership is one of the issues that is often faced today. The importance of management as a tool in human life has always been a special consideration, which in this case is centred on the leader. A leader is a system of driving a job, where he has the expertise to apply management functions in decisions made, the leadership power in organizations even in politics can influence the organization through policies (rules) and regulations (policies) that can facilitate the achievement of the goals of the organization effectively and efficiently.

Motivation has a close relationship with attitudes and behavior possessed by someone, so that motivation can be interpreted as a condition in one's personal self so that the person is motivated to do an activity or activity. Therefore, motivation has the nature that will not be separated from human nature itself, where humans individually have a quality of self-existence, background and attitudes that differ from one another, so that the motivation that arises in each individual is different different.

Spiritual intelligence is intelligence that relies on the inner self that is associated with wisdom outside the ego 
or soul consciousness. This is in line with research conducted by Moore, et al., Saying that basically spiritual intelligence is very influential on job satisfaction. From this research it can be revealed that the spiritual intelligence of employees will affect job satisfaction. The more intelligent the employee, the level of satisfaction with work will also increase. With high spiritual intelligence, people will be able to interpret positively on every event, problem and even the suffering they experience, so they will be able to awaken their souls and carry out positive positive actions and actions. In addition, spiritual intelligence can also create courage in action, calmer and on target while solving problems and more to the sense of humanity or justice to sort out the type of reaction.

Job satisfaction is an important thing that individuals have at work. Each individual worker has different characteristics, so the level of job satisfaction also varies - the high and low levels of job satisfaction can have different effects. The measurement of satisfaction is very based on the reality faced and received as compensation for the effort and energy provided. Job satisfaction depends on the suitability or balance between the expected and reality.

To support the government program, the existence of human resources in an organization, especially the Office of Maritime Affairs and Fisheries of the Riau Islands Province plays a very important role. Organizations must be able to build and improve performance in their environment by taking into account the real needs of a good government system. For that the organization must take several ways to create a work climate that is relevant to good governance including leadership behaviour, work motivation of employees, spiritual intelligence, and good performance so as to encourage employees to be satisfied with the achievements achieved that support the organization's goals.

\subsection{Formulation of the problem}

The following problem formulations in this study are as follows:

1. Does the leader's behavior determine directly the performance of employees at the Department of Maritime Affairs and Fisheries of the Riau Islands Province.

2. Does work motivation directly determine the performance of employees at the Department of Maritime Affairs and Fisheries of the Riau Islands Province.

3. Does spiritual intelligence directly determine the performance of employees at the Department of Maritime Affairs and Fisheries of the Riau Islands Province.

4. Does the leader's behavior determine directly the job satisfaction of the Department of Maritime Affairs and Fisheries of the Riau Islands Province.

5. Does work motivation directly determine job satisfaction at the Department of Maritime Affairs and Fisheries of the Riau Islands Province.

6. Does spiritual intelligence directly determine job satisfaction at the Department of Maritime Affairs and Fisheries of Riau Islands Province.

7. Does job satisfaction directly determine the performance of employees at the Department of Maritime Affairs and Fisheries of the Riau Islands Province.

\section{Literatur Review}

\subsection{Leadership Behavior}

The problem of leadership is one of the issues that is often faced today. The importance of management as a tool in human life has always been a special consideration, which in this case is centered on the leader. A leader is a system of driving a job, where he has the expertise to apply management functions in decisions made, then leadership power in organizations even in politics can influence the organization through policies (rules) and regulations (policies) that can facilitate the achievement of the goals of the organization effectively and efficiently (Djafri, 2017).

\subsection{Motivation}

Motivation is the "ability to do" something while the motive is "the need, desire, drive to do something". There are several factors that affect motivation, including the stimulation of strength and the intrinsic aspects of an individual. This does not rule out the possibility that external stimuli can affect motivation, it's just that motivation is a reflection of a person's reaction to a stimulus. In its concept, motivation is "the result of a number of processes, which are internal or external to an individual, which causes an attitude of enthusiasm and persistence in terms of carrying out certain activities" (Djafri, 2017).

\subsection{Spiritual Intelligence}

According to experts, there are many intelligences given by God to humans. One of them is spiritual intelligence (SQ), this intelligence is an intelligence that elevates the function of the soul as an internal device of the self that has the ability and sensitivity in seeing the meaning behind a reality or certain events. Spiritual intelligence (SQ) which is closely related to the question of meaning and value was first conceived and discovered by Danah Zohar 
and Ian Marshall. According to Zohar and Marshall in his book Wahyudi Siswanto explained that spiritual intelligence in terminology is the main intelligence with which it can solve problems of meaning and value, placing action or a way of life in a broader, richer, and meaningful context (Siswanto, 2012).

\subsection{Job satisfaction}

(Robbins \& Judge, 2008) stated that job satisfaction is a general attitude towards one's work as the difference between the amount of rewards received by workers and the amount of rewards that are believed to be received. Job satisfaction is an important thing that individuals have at work. Each individual worker has different characteristics, so the level of job satisfaction also varies - the high and low levels of job satisfaction can have different effects. The measurement of satisfaction is very based on the reality faced and received as compensation for the effort and energy provided. Job satisfaction depends on the suitability or balance between the expected and reality.

\subsection{Employee Performance}

(Mangkunegara \& Prabu, 2015) The term performance comes from the word Job Performance or Actual Performance (work performance or actual achievement achieved by someone). Understanding performance (work performance) is the work of quality and quantity that someone has achieved with responsibilities that given to him. Factors that affect employee performance are the ability factor (ability) and motivation factor (motivation).

\subsection{Theoretical Framework}

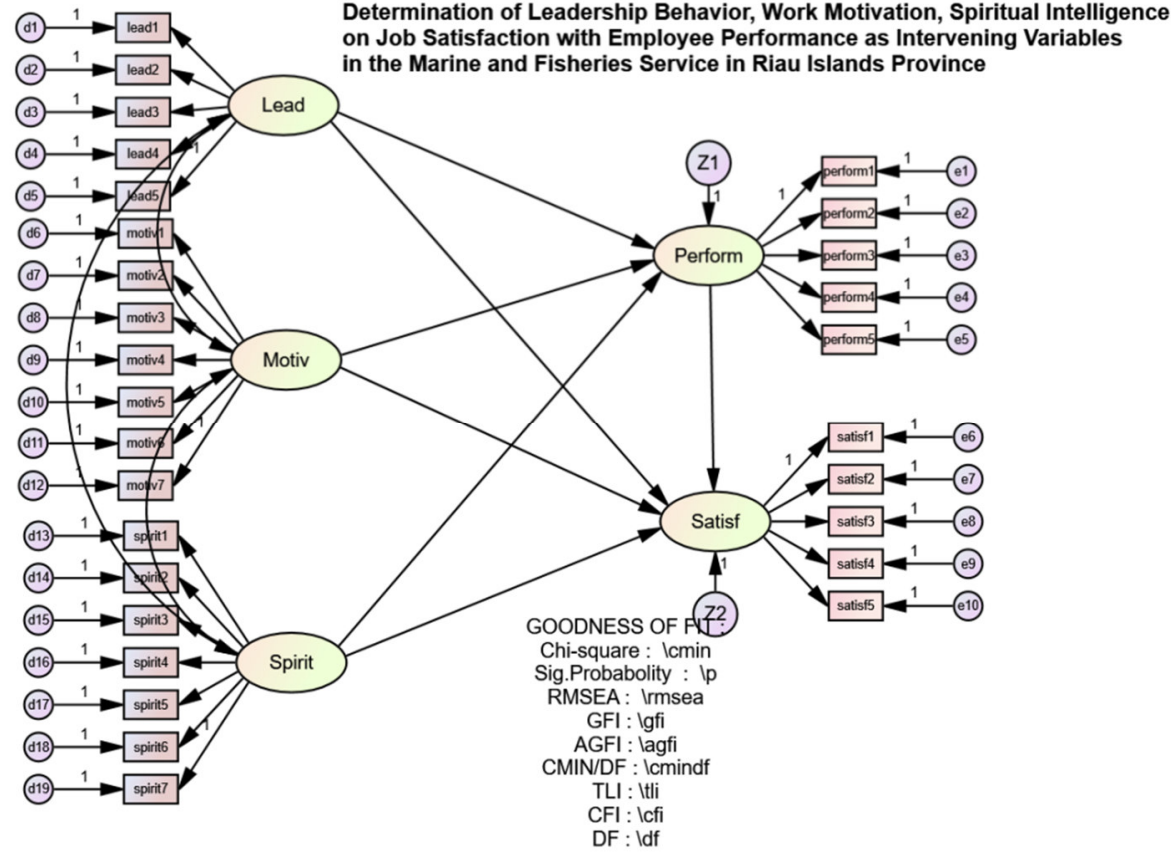

\subsection{Research Hypothesis}

The hypotheses in this study are as follows:

1. Leadership behavior directly determines the performance of employees of the Marine and Fisheries Service of the Riau Islands Province

2. Work Motivation determines directly on the performance of employees of the Marine and Fisheries Service of the Riau Islands Province

3. Spiritual intelligence determines directly on the performance of employees of the Office of Maritime Affairs and Fisheries of the Riau Islands Province

4. The leader's behavior directly determines the job satisfaction of the Department of Maritime Affairs and Fisheries of the Riau Islands Province

5. Work motivation directly determines the job satisfaction of the Department of Maritime Affairs and Fisheries of the Riau Islands Province

6. Spiritual intelligence determines directly the job satisfaction of the Marine and Fisheries Service of the Riau Islands Province

7. Job satisfaction determines directly on the performance of employees of the Department of Maritime Affairs and Fisheries of the Riau Islands Province 


\section{Research Method}

\subsection{Research Types and Data Sources}

This type of research is quantitative with survey methods and questionnaires distributed to employees of the Department of Maritime Affairs and Fisheries of the Riau Islands Province. The data used in this study are primary data and secondary data.

\subsection{Population}

Population is a generalization of all subjects and objects of existing research. The population in this study were 120 employees of the Maritime Affairs and Fisheries Office of the Riau Islands Province.

\subsection{Sample}

In accordance with the characteristics of the study, the samples needed are employees related to the research variables, so the non-probability sampling technique chosen is judgmental (purposive) technique. This technique was chosen to ensure that only samples which had certain elements predetermined by researchers would be taken as samples. In this study the sample taken was an employee of the Department of Maritime Affairs and Fisheries of the Riau Islands Province with a total of 120 respondents.

\subsection{Data collection technique}

For the purposes of the analysis of the problem under study, the data collection is carried out using techniques: 1) Distribution of questionnaires that contains questions from each research variable. Then the questions are weighted on a Likert scale with a weighting of 1 to 5.2) Document Study, namely studying and observing data or reports contained in the Marine and Fisheries Service of the Riau Islands Province.

\subsection{Research variable}

This study analyzes five main variables, namely leadership behavior (X1), work motivation (X2) and spiritual intelligence (X3) as exogenous variables, employee performance (Y) as an intervening variable and job satisfaction $(Z)$ as endogenous variables.

\subsection{Data analysis method}

In this study the following analysis tools were used:

1. Test Validity and Reliability

The criterion for testing validity is to compare $r$ count with $r_{\text {tables }}$, at a significant level of $95 \%$ or $=5 \%$. According to (Sugiyono, 2013), the question item is called valid if the question item has $r_{\text {count }} \alpha$ The criterion for testing validity is to compare $r_{\text {count }}$ with $r_{\text {tables, }}$, at a significant level of $95 \%$ or $>$ standard $=0.30$. In this case, what is meant is calculated for each question item, the product moment correlation coefficient between the scores of each item is the total score of all items notated with Corrected Item Total Correlation in the calculation results of the SPSS 23.0 program. While, to test the reliability of a list of statements from a piece of research variable used Cronbach's Alpha coefficient. The magnitude of Cronbach's Alpha coefficient indicates the level of reliability of the statement. A construct of variables is said to be reliable if it has a Cronbach's value $>$ of 0.60 . Calculation of product moment correlation and Cronbach's Alphabet Coefficient was done with SPSS for Windows version 23.0 specifically on the Scale sub menu on the Analyze menu.

\section{SEM Assumption Test}

The analysis used by researchers in this study is path analysis that is by describing a flow chart that can make it easier to see the relationships to be tested. Data analysis was performed using the Structural Equation Modeling (SEM) method and the software used for structural analysis was Amos version 24. In this step the suitability of the model was evaluated, by examining various criteria of Goodness of Fit. For that the first step taken was to evaluate whether the data used can meet the SEM assumptions. If these assumptions are met, then the model can be tested. According to Ferdinand the assumptions that must be fulfilled in the data collection and processing procedures analyzed by SEM modeling (Ferdinand, 2002) 


\section{Result and Discussion}

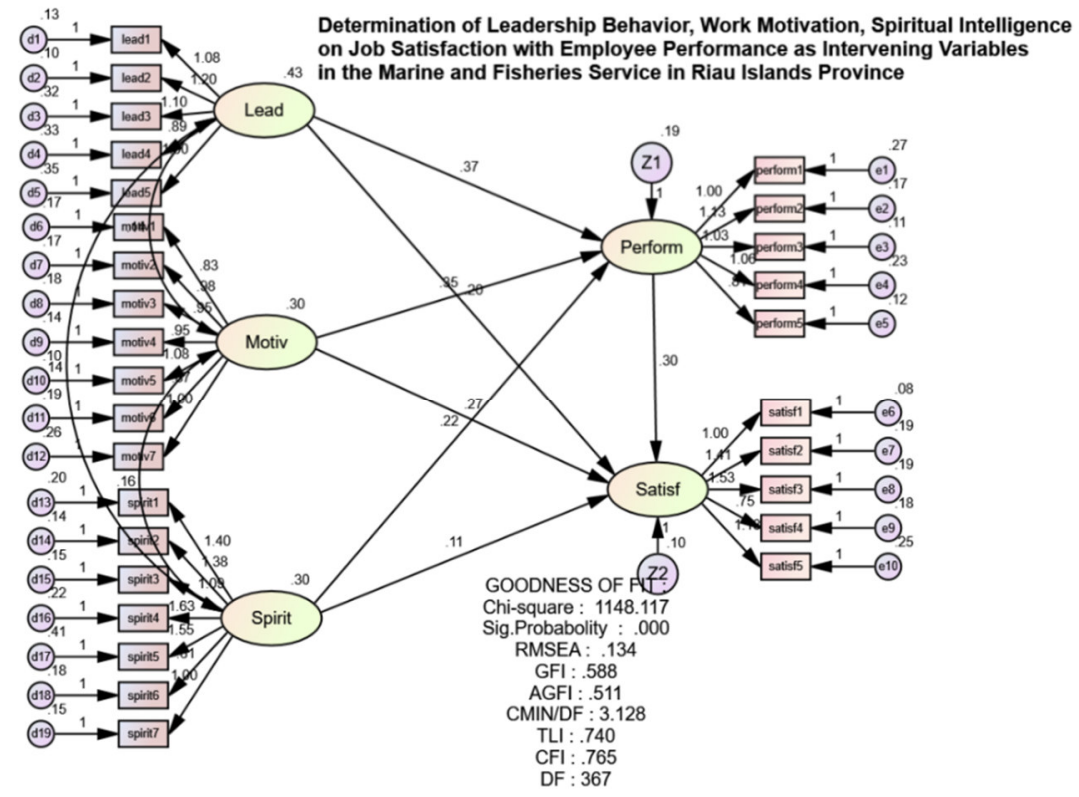

\section{Analisys Goodness of Fit}

Based on the test criteria, Chi-square ( $\chi 2$ ), Relative Chi-square ( $\chi 2$ / df), RMSEA, GFI, AGFI, TLI, and CFI above and the Goodness of Fit value of Amos for Windows processing version 24.0 as shown in the figure 2 above, the table can be made as follows:

Table 1 Goodness Of Fit Evaluation

\begin{tabular}{|l|c|c|c|}
\hline \multicolumn{1}{|c|}{ Goodness of Fit Index } & Cut-of Value & Model Resultsinformation \\
\hline Chi-square $\left(\chi^{2}\right)$ & Is expected small & 1148.117 & Poor \\
\hline Relatitive Chi-Square $\left(\chi^{2} / \mathrm{df}\right)$ & $\leq 3,00$ & 3.128 & Good \\
\hline Probability & $>0,05$ & 0,000 & Good \\
\hline RMSEA & $\leq 0,08$ & 0,134 & Poor \\
\hline GFI & $\geq 0,90$ & 0,588 & Poor \\
\hline AGFI & $\geq 0,90$ & 0,511 & Marginal \\
\hline TLI & $\geq 0,94$ & 0,740 & Marginal \\
\hline CFI & $>0,94$ & 0,765 & Marginal \\
\hline
\end{tabular}

Based on the table above shows that more than 2 goodness of fit criteria have met the cut off value, it is that the evaluation results show a good model. This explains that the model used in this study produced the expected level of estimation. Thus this model is a good model and feasible to explain the relationship between variables in the model. Standardized Regression Weight (Lamda) Indicators of Leadership Behavior, Work Motivation, Spiritual Intelligence, Employee.

Table 2 Performance and Job Satisfaction

\begin{tabular}{|c|c|c|c|}
\hline & & & Estimate \\
\hline Perform & $<---$ & Lead & .387 \\
\hline Perform & $<---$ & Motiv & .312 \\
\hline Perform & $<---$ & Spirit & .197 \\
\hline Satisf & $<---$ & Perform & .349 \\
\hline Satisf & $<---$ & Lead & .248 \\
\hline Satisf & $<---$ & Motiv & .278 \\
\hline Satisf & $<---$ & Spirit & .111 \\
\hline
\end{tabular}


Table 3 Regression Weight (Lamda) Leadership Behavior, Work Motivation, Spiritual Intelligence, Employee Performance and Job Satisfaction

\begin{tabular}{|ll|r|r|r|r|l|}
\hline & & Estimate & S.E. & C.R. & P & Label \\
\hline Perform $<---$ & Lead & .368 & .089 & 4.124 & $* * *$ & par_25 \\
\hline Perform $<---$ & Motiv & .355 & .114 & 3.101 & .002 & par_26 \\
\hline Perform $<---$ & Spirit & .224 & .108 & 2.078 & .038 & par_27 \\
\hline Satisf $<---$ & Perform & .302 & .090 & 3.349 & $* * *$ & par_28 \\
\hline Satisf $<---$ & Lead & .204 & .072 & 2.836 & .005 & par_29 \\
\hline Satisf $<---$ & Motiv & .274 & .096 & 2.842 & .004 & par_30 \\
\hline Satisf $<---$ & Spirit & .109 & .084 & 1.303 & .193 & par_31 \\
\hline
\end{tabular}

Table 4 Squared Multiple Correlations: (Group number 1 - Default model)

\begin{tabular}{|l|r|}
\hline & Estimate \\
\hline Perform & .511 \\
\hline Satisf & .638 \\
\hline
\end{tabular}

Source: Output IBM SPSS AMOS 24 (2020)

From the results of the regression analysis both partially and jointly between leadership behavior variables, work motivation and spiritual intelligence on job satisfaction with employee performance as an intervening in the Marine and Fisheries Service of the Riau Islands Province as follows:

1. Leadership Behavior Towards Employee Performance

From the results of data analysis above, it can be seen that the determination of the latent variables of Leadership Behavior to the Employee Performance variable (performance) has a standardized estimate (regression weight) of 0.387 with $\mathrm{Cr}$ (Critical ratio = identical to the t-count value) of 4.124 on a smaller probability from $0.05(* * *)$. CR value 4.124> 2.00 and Probability $=(* * *)<0.05$ indicates that the determination of the leader's latent variable (lead) to the latent variable Employee Performance (performance) is positive and significant. The theory that supports this finding is that leadership is an activity to influence people to be directed towards achieving organizational goals. Leadership also includes the process of influencing in determining organizational goals, motivating followers' behavior to achieve organizational goals, influencing to improve the group and its culture (Miftah, 2010). which defines motivation as the internal state of the individual which gives birth to strength, excitement and dynamics, and directs behavior toward the goal. From the results of this study it can be seen that the Work Motivation of the Marine and Fisheries Service Office of the Riau Islands Province is quite good, the Work Motivation encourages employees to do work outside of their job descriptions. This is in line with the theory of Organ (2006) which states that with the existence of internal and ongoing motivation that comes from within the individual because of the intrinsic need for achievement, competence, and affiliation that will lead to improving employee performance. In line with previous research conducted by (Cahyono, 2012) leadership has a significant positive effect on employee performance (performance).

2. Work Motivation Toward Employee Performance

Determination of latent variables Work Motivation (motiv) to latent variables Employee Performance (performance) has a standardized estimate (regression weight) of 0.312 with $\mathrm{Cr}$ (Critical ratio $=$ identical to the tcount value) of 3.101 at probability $=0.002$. CR value $3.101<2,000$ and Probability $=0.002>0.05$ indicates that the determination of the latent variable of Work Motivation (motiv) to the latent variable Employee Performance (performance) is Positive and Significant. Work Motivation determines Employee Performance (performance). Based on the theory The results of this study are supported also by the results of previous studies examined by (Cahyono, 2012) found that based on the results of the analysis prove that work motivation has a significant effect on performance and also the variable of work motivation has a partial and simultaneous influence on employee performance. Based on the theory according to (Sunyoto, 2013) states work motivation is a condition that encourages the desire of individuals to carry out certain activities to achieve their desires. Existing motivation in a person is the power that will manifest a behavior in achieving the goal of self satisfaction in a specific type of activity, and the direction is positive by aiming to approach the object that is the goal. This was not seen in the results of this study. Work Motivation at the Department of Maritime Affairs and Fisheries of the Riau Islands Province is able to foster enthusiasm and enthusiasm and motivation of employees to help each other and do work to improve employee performance.

3. Spiritual Intelligence on Employee Performance

Determination of the latent variable Spiritual Intelligence (spirit) on the latent variable Employee Performance (performance) has a standardized estimate (regression weight) of 0.197 with a $\mathrm{Cr}$ (Critical ratio $=$ identical to the $\mathrm{t}$-count value) of 2.078 at a probability $=0.038$. CR value $=2.078>2,000$ and Probability $=0.038<0.05$ indicates that the determination of the latent variable Spiritual Intelligence (spirit) on the latent variable Employee Performance (performance) is Positive and Significant. Spiritual intelligence has no effect on employee 
performance, this is as revealed by Hardiat (2016) spiritual intelligence is motivation that encourages a person's performance to do better than what has been made or previously achieved or that was made or achieved by others and can be measured. And based on expert opinion that spiritual intelligence has an influence on many effects in human life and in the workplace. Based on the theory The results of this study are also supported by the results of previous studies examined by (Suhartini \& Anisa, 2017) that spiritual intelligence has a positive effect on employee performance.

4. Leadership Behavior Towards Job Satisfaction

Determination of latent variables Leadership behavior (lead) to the latent variable Job Satisfaction (satisf) which has a standardized estimate (regression weight) of 0.248 with $\mathrm{Cr}$ (Critical ratio = identical to the t-count value) of 2.836 at probability $=0,005$. CR value 2,836>2,000 and Probability $=0,005<0.05$ indicates that the determination of the Leadership latent variable (lead) to the latent variable Job Satisfaction (satisf) is Positive and Significant. From this study shows that the variable Leadership Behavior has a dominant influence on job satisfaction. Spiritual intelligence is intelligence that relies on the inner self associated with wisdom outside the ego or soul consciousness contrary to the research conducted by Moore, et al, who said that basically leadership behavior is very influential on job satisfaction. In this case it can be revealed that the employee's spiritual intelligence does not affect job satisfaction. The higher the spiritual intelligence of the employee will be able to interpret positively on every event, problem and even the suffering experienced, then he will be able to awaken his soul and be satisfied with the work achieved. Previous research was conducted by (Darmayanti, 2016) who stated that there was a positive and significant influence of leadership behavior on job satisfaction.

5. Work Motivation Towards Job Satisfaction

Determination of latent variables Work motivation (motiv) to latent variables Job Satisfaction (satisf) has a standardized estimate (regression weight) of 0.278 , with $\mathrm{Cr}$ (Critical ratio $=$ identical to the t-count value) of 2.842 at probability $=0.004$. CR value $2.842<2,000$ and Probability $=0.004>0.05$ indicates that the determination of the latent variable of Work Motivation (motiv) to the latent variable Job Satisfaction (satisf) is Positive and. From this study shows that the variable Work Motivation determines predominantly on Job Satisfaction (Golung, 2012) states that employee performance basically depends on many factors such as employee work motivation, employee satisfaction, compensation, training and development, job security, structure organization and others. The results of this study are the same as research conducted by (Darmayanti, 2016) where Work Motivation and Leadership Behavior simultaneously have a positive and significant effect on Job Satisfaction.

6. Spiritual Intelligence on Job Satisfaction

Determination of the latent variable Spiritual Intelligence (spirit) on the latent variable Job Satisfaction (satisf) has a standardized estimate (regression weight) of 0.111 with $\mathrm{Cr}$ (Criticalratio $=$ identical to the t-value) of 1.303 at probability $=0.193$. CR value $1.303<2,000$ and Probability $=0.193>0.05$ indicates that the influence of the latent variable Spiritual Intelligence (spirit) on the latent variable Job Satisfaction (satisf) is Positive Not significant. This shows that the Spiritual Intelligence of Marine and Fisheries Department employees in Riau Islands Province has a positive but not significant effect on employee job satisfaction. From this study shows that the variable of spiritual intelligence does not have a dominant influence on job satisfaction. Spiritual intelligence is intelligence that is based on the inside of oneself which is related to wisdom outside the ego or the soul of consciousness contrary to the research carried out by Moore, et al, who said that basically leadership behavior is very influential on job satisfaction. In this case it can be revealed that the employee's spiritual intelligence does not affect job satisfaction. The higher the spiritual intelligence of the employee will be able to interpret positively on every event, problem and even the suffering experienced, then he will be able to awaken his soul and be satisfied with the work achieved. The results of this study are inversely proportional to the results of previous studies conducted by (Ilham, 2014) which states there is a positive direct effect of spiritual intelligence on job satisfaction.

7. Employee Performance Against Job Satisfaction

Determination of latent variables Employee Performance (performance) of latent variables Job Satisfaction (satisf) has a standardized estimate (regression weight) of 0.349 , with $\mathrm{Cr}$ (Critical ratio = identical to the t-count value) of 3.349 at probability $=* * *$. CR value $3,349<2,000$ and Probability $=* * *<0.05$ shows that the influence of latent variables Employee Performance (performance) on the latent variable Job Satisfaction (satisf) is Positive and Significant, so it can be said that Employee Performance (performance) as a moderating variable determine the Leadership Behavior, Work Motivation, and Spiritual Intelligence on Job Satisfaction. According to (Martínez et al., 2012) describing job satisfaction as a positive or negative attitude done individually to their work, then according to (Handoko, 2011) defines performance appraisal or work performance (performance appraisal) is the process of an organization evaluating or assess employee work performance. Through good employee performance, employees of the Office of Maritime Affairs and Fisheries of the Riau Islands Province are able to show mutual assistance, support each other, and work optimally to achieve organizational goals, so that through these actions can encourage employee work motivation and employee performance. In line with this theory, (Wijaya, 2018) proves that job satisfaction has a positive and significant effect on employee performance. 


\section{Conclusion}

Based on the results of the research analysis it can be concluded as follows:

1. Determination of latent variables Leadership behavior to latent variables Employee Performance is positive and significant.

2. Determination of latent variables Work motivation to latent variables Employee Performance is Positive and Significant.

3. Determination of latent variables Spiritual Intelligence on latent variables Employee Performance is Positive and Significant.

4. Determination of latent variables Leadership behavior to the latent variables Job Satisfaction is Positive and Significant.

5. Determination of latent variables Work motivation to the latent variable Job Satisfaction is Positive and Significant.

6. Determination of the latent variable Spiritual Intelligence on the latent variable Job Satisfaction is Positive Not significant.

7. Derivation of latent variables Employee Performance to the latent variable Job Satisfaction is Positive and Significant.

8. Latent Variables Employee Performance mediates the latent variable Leadership Behavior (lead) to the variable Job Satisfaction.

9. Latent variables Employee Performance does not mediate the latent variable Work Motivation on the variable Job Satisfaction.

10. Latent variables Employee Performance does not mediate the latent variable Spiritual Intelligence on the variable Job Satisfaction.

11. Changes in Employee Performance are determined by Leadership Behavior, Work Motivation, Spiritual Intelligence, and Job Satisfaction by $51.1 \%$, while changes in Job Satisfaction are determined by Leadership Behavior, Work Motivation, Spiritual Intelligence by $63.8 \%$.

\section{References}

Cahyono, A. (2012). Analisa pengaruh kepemimpinan, motivasi dan budaya organisasi terhadap kinerja dosen dan karyawan di Universitas Pawyatan Daha Kediri. Jurnal Ilmu Manajemen, Revitalisasi, 1(1), $283-298$.

Darmayanti, N. W. P. (2016). Pengaruh Perilaku Pemimpin Terhadap Motivasi Kerja, Kepuasan Kerja Dan Kinerja Guru Dan Pegawai Di Lingkungan Unit Sma Dwijendra Denpasar. Udayana University.

Djafri, N. (2017). Manajemen Kepemimpinan Kepala Sekolah:(Pengetahuan Manajemen, Efektivitas, Kemandirian Keunggulan Bersaing dan Kecerdasan Emosi). Deepublish.

Ferdinand, A. (2002). Structural equation modeling dalam penelitian manajemen. Semarang: Badan Penerbit Universitas Diponegoro.

Golung, A. G. (2012). KAJIAN KEMAMPUAN DAN FAKTOR-FAKTOR YANG BERHUBUNGAN DALAM PENGOLAHAN BAHAN PUSTAKA DI UPT PERPUSTAKAAN UNSRAT MANADO. Jurnal Ilmu Komunikasi" JIKOM", 1(1), 67-72.

Handoko, H. (2011). Dasar-Dasar Manajemen Produksi Dan Operasi Yogyakarta: BPFE.

Ilham. (2014). Analisis pengaruh kecerdasan Emosional, Kecerdasan Spiritual dan Organization Citizenship Behavior Terhadap kinerja Aparatur Sipil Negara (Studi Empiris di Dinas Kebersihan Kota Ternate). Universitas Terbuka.

Mangkunegara, A. P., \& Prabu, A. (2015). Manajemen Sumber Daya Manusia Perusahaan, Cetakan kedua belas. Penerbit PT. Remaja Rosda Karya Offset, Bandung.

Martínez, M. E., Thompson, P., Messer, K., Ashbeck, E. L., Lieberman, D. A., Baron, J. A., Ahnen, D. J., Robertson, D. J., Jacobs, E. T., \& Greenberg, E. R. (2012). One-year risk for advanced colorectal neoplasia: US versus UK risk-stratification guidelines. Annals of Internal Medicine, 157(12), 856-864.

Miftah, T. (2010). Kepemimpinan dalam manajemen. Jakarta: Rajawali Pers.

Robbins, S. P., \& Judge, T. A. (2008). Perilaku organisasi edisi ke-12. Jakarta: Salemba Empat, 11.

Siswanto, V. A. (2012). Strategi dan langkah-langkah penelitian. Yogyakarta: Graha Ilmu.

Sugiyono, P. D. (2013). Statistik untuk Penelitian. CV. Alvabeta Bandung.

Suhartini, E., \& Anisa, N. (2017). Pengaruh Kecerdasan Emosional dan Kecerdasan Spiritual terhadap Kinerja Perawat Rumah Sakit Daerah Labuang Baji Makassar. Jurnal Minds: Manajemen Ide Dan Inspirasi, 4(1).

Sunyoto, D. (2013). Manajemen Sumber Daya Manusia, cetakan ke-2, PT. Buku Seru, Jakarta.

Wijaya, I. K. (2018). Pengaruh Kepuasan Kerja Terhadap Kinerja Karyawan CV Bukit Sanomas. Agora, 6(2). 